\title{
A Close-up on National Venezuelan Film Support during the Chávez Years: Between Revolution and Continuity
}

\author{
Michelle Leigh Farrell \\ Fairfield University, mfarrell3@fairfield.edu
}

Follow this and additional works at: https://digitalcommons.fairfield.edu/modernlanguagesandliteraturefacultypubs

Copyright 2016 Wiley. Post-print archived here with permission from the copyright holder with a 2 year embargo. "This is the peer reviewed version of the following article: A Close-up on National Venezuelan Film Support during the Chávez Years: Between Revolution and Continuity. The Latin Americanist, 60(3), pp.371-390, which has been published in final form at [DOI: 10.1111/tla.12084,]. This article may be used for non-commercial purposes in accordance with Wiley Terms and Conditions for Self-Archiving."

\section{Peer Reviewed}

\section{Repository Citation}

Farrell, Michelle Leigh, "A Close-up on National Venezuelan Film Support during the Chávez Years: Between Revolution and Continuity" (2016). Modern Languages \& Literature Faculty Publications. 32. https://digitalcommons.fairfield.edu/modernlanguagesandliterature-facultypubs/32

\section{Published Citation}

Farrell, M.L., Sept. 2016. A Close-up on National Venezuelan Film Support during the Chávez Years: Between Revolution and Continuity. The Latin Americanist, 60(3), pp.371-390. DOI: 10.1111/tla.12084

This item has been accepted for inclusion in DigitalCommons@Fairfield by an authorized administrator of DigitalCommons@Fairfield. It is brought to you by DigitalCommons@Fairfield with permission from the rightsholder(s) and is protected by copyright and/or related rights. You are free to use this item in any way that is permitted by the copyright and related rights legislation that applies to your use. For other uses, you need to obtain permission from the rights-holder(s) directly, unless additional rights are indicated by a Creative Commons license in the record and/or on the work itself. For more information, please contact digitalcommons@fairfield.edu. 
Title: A Close-up on National Venezuelan Film Support during the Chávez Years: Between Revolution and Continuity

Keywords: Venezuela, film, Chávez, Villa del Cine, CNAC, Cinemateca

\begin{abstract}
:
The Venezuelan state's active role in the film industry during the Chávez years resulted in controversy both within and beyond Venezuela. With an aggressive national film law, and new state film institutions, the turn to film caused an unprecedented boom in Venezuelan filmmaking and a flood of press coverage. Chávez's public announcements celebrated the government's active investment in filmmaking likening the venture in film with a break from the past. I explore how the Venezuelan government under Chávez both ruptured with the previous relationship between the film industry and the government while also continued with past state film initiatives despite revolutionary discourse. While much of the research and press on Venezuelan film under Chávez often focuses on the institution that Chávez praised most, the politically aligned and controversial Villa del Cine (2006), I show that the well-known Villa does not entirely represent the role of the state in supporting Venezuelan film during the Chávez years. The Villa is part of the much larger understudied National Film Platform. With a close look at three of the state film institutions from the Platform, I examine the complex workings of the state/film relationship under Chávez hovering between continuing and breaking with the past.
\end{abstract}

\title{
Introduction:
}

On June 4, 2006, during his weekly unscripted, and famously lengthy television program, Aló, Presidente [Hello, President], President Hugo Chávez announced the Venezuelan government's investment in film and, more specifically, in a new national film production company La Villa del Cine. He proposed that the government's decision to support and invest in Venezuelan filmmaking was not only about making movies. On air Chávez explained:

Venezuelan film will be for the world, as Bolívar said: "Weapons of thought"artillery of our culture, artillery of our essence...we are going to make quality movies! (Aló Presidente, Programa 257)

In the above quote Chávez makes an allusion to two key moments in Venezuelan and Latin American history. First by evoking the single most celebrated figure in Latin 
American history and father of the Venezuelan nation, Simón Bolívar, Chávez explicitly connects domestic filmmaking with the country's independence and original mission celebrating national cultural sovereignty. Second, Chávez discusses films as the "artillery" of the nation, recognizing the power of the movies as active cultural products with the ability to teach as well as protect the nation, connecting films with revolutionary discourse. The film-weapon relationship not only borrows from Bolívar's famous words about the power of thoughts as artillery, but also conjures a dialogue with the celebrated film manifestos of the 1960s from the vanguard Brazilian filmmaker Glauber Rocha to Cuban filmmaker Julio García Espinosa that shaped the most renowned movement in Latin American filmmaking: New Latin American Cinema in the 1960s and beyond. This complex continent-wide initiative used film precisely to break from cultural and political hegemony and disengaged high budget filmmaking. Both Rocha and García Espinosa's manifestos have served as foundational works to the cinemas of Latin America calling for low budget, aesthetically simple films, committed to freeing the audiences from the grip of Hollywood and the violence of colonialism.

Chávez continues to revive the language of New Latin American Cinema to share the film/state relationship with his television viewers in the same Aló Presidente program. In doing so he announces the largest investment in film under his administration- the creation of the state production company La Villa del Cine:

Yesterday...we assigned resources to the Ministry of Culture to continue making a second step in this marvel--did you see it yesterday?--La Villa del Cine. We are going to make quality movies to compete with the best Hollywood films...They 
have a film dictatorship controlling us! For every 100 films shown in Latin America, 96 come from Hollywood! (Aló Presidente 257)

Making an explicit connection between filmmaking and soveregnity, Chávez frames this revolutionary investment in cinema as one that not only breaks with Hollywood's monopoly on movie screens throughout Latin America but also with a cultural dictatorship.

This change in Venezuelan state supported filmmaking, creating the highly visible and controversial Villa made headlines domestically and abroad. With articles in US and European press such as "Venezuelan cinema, Chavez style" $(B B C)$, "Chávez Takes 'Crazy Battalion' of Supporters on the Road" (The New York Times), "Venezuelan President Hugo Chavez's Movie Studio” (Newsweek), "Lights, Camera, Revolution,” (Newsweek) and "Venezuela's Chavez Promotes Nation's Films" (NPR), the focus was solely on La Villa, and immediately likened filmmaking under Chávez with explicit state propaganda. Academic research has also dedicated much space to the state film production institution, La Villa del Cine that has greatly contributed to Venezuelan filmmaking during the Chávez era (Hellinger, Kozloff, Valladares-Ruiz, and Zweig).

While La Villa is a key part of the Chávez administration's legacy on film causing much public admiration and controversy, in this article I show that it does not represent the complete picture of the film initiative under Chávez. Instead La Villa is the film organization most aligned with the government and focuses on "increasing filmmaking to contribute to the legitimacy and justification of the Revolution's social project" (Suárez 3). In fact, while echoing the film as weapon image, unlike the low budget socially committed films of the New Latin American Cinema project, La Villa films are some of 
the highest budgeted films in Latin America. La Villa del Cine produced film Libertador (2013), for example, is the most expensive film in the history of Latin American cinema with a budge of fifty million dollars (González).

La Villa is part of a complex, loosely organized, under-researched, larger initiative created during the Chávez administration known as the National Film Platform. I explore how despite the surrounding revolutionary discourse of rupture and novelty, the Chávez-era Film Platform was a multifaceted, complex (and even contingent) enterprise, which contained as much of the "old" as the new despite the radical discourse. The Venezuelan state did not dismantle past institutions; instead it added to previous institutions creating a disorganized maze of state film support.

This intricate combination of old and new institutions is typical of the Chávez legacy in many sectors, where traces of the past and new socialist initiatives co-exist in what sociologist Sujatha Fernandes refers to as "Venezuelan particularism" (23). Fernandes explains that: "[t]he Venezuelan case contains both continuities and ruptures with the past. For the most part, new policies and orientations are being fashioned from within neoliberal state institutions, bounded by but also reshaping these institutions" (23). While Fernandes' research focuses on urban social movements, and not specifically on the film industry, I show how the combination of continuities and ruptures with the past also exists within the state institutions dedicated to film—resulting in an array of films both aligned and unaligned with the Chávez administration.

Under Chávez, the five different film organizations with roots in various past administrations had diverse funding structures, and separate selection committees that coexisted during the second Chávez administration. These differing institutions, with 
varying affiliations with the state, worked separately, leading to disorganization and at times incompatible projects. However, I argue that this disorganization and patchwork of film initiatives may have been Venezuela's strength rather than weakness in film during the Chávez administrations bringing both chaos and opportunity.

\section{Venezuelan Film Platform}

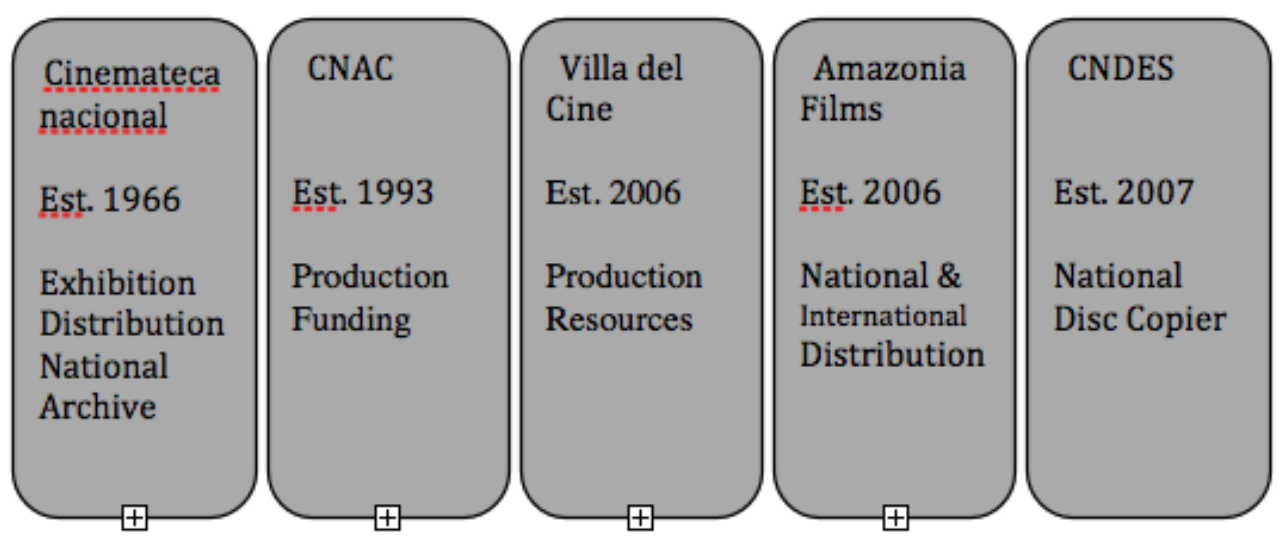

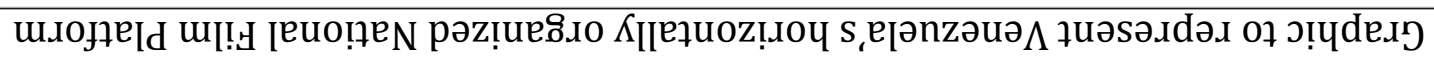

To explore this possible tension between chaos and opportunity, of the five institutions I focus closely on the most controversial, visible and government aligned, La Villa del Cine, in dialogue with the two oldest, and most active film institutions in Venezuela: the CNAC and the Cinemateca Nacional. The latter two institutions CNDES and Amazonia Films, do not add to the present tension in contemporary Venezuelan film. They were established after La Villa and have more straightforward roles in filmmaking causing much less controversy. 
I show how the lack of communication between institutions embodies the Film Platform's disorganization allowing for a diverse range of films in ways that have been neglected in studies on film under Chávez. Finally, I explore how these institutions both address decades-long challenges in Venezuelan filmmaking: film distribution and exhibition, while also fall short in addressing a constant obstacle: Caracas-centric cultural support.

\section{The State and Filmmaking:}

Despite the controversy over Chávez's film announcements in his program Aló Presidente, the Venezuelan government's interest in making movies did not begin during the Chávez-era. Instead the country has a history of state support for filmmaking to offset the exorbitant costs of making movies. Venezuela is not alone in creating state initiatives to support filmmaking and is most often compared with the region's revolutionary model: Cuba. Cuba serves as a strong point of comparison as it has played a key role in the Chávez administration as Chávez fostered a close relationship with Fidel and later Raúl Castro as well as establishing Cuban/Venezuelan economic and cultural initiatives throughout the Chávez presidency. This relationship was visible in a range of areas, from clinics with Cuban doctors in the Misión Barrio Adentro ${ }^{1}$ to literacy work with the Misión Rivas and inviting teams of Cuban specialists in culture, theater, and filmmaking to serve as advisers in Venezuela. Upon the creation of La Villa, a parallel between Venezuelan and Cuban filmmaking began to form, likening Venezuela to Cuba's model, Zweig comments that: "[m]uch of the inspiration for [the] Villa del Cine comes from the

\footnotetext{
${ }^{1}$ See Cooper for more on Barrio Adentro.
} 
cinema propelling the Cuban Revolution of 1959"(138). Villazana further discusses that Cuba and Venezuela are unique in terms of Latin American film: "con el lanzamiento de proyectos como la distribuidora nacional [venezolana] Amazonia Films a través de la cual Venezuela pasa a ser el único país en América Latina -a excepción de Cuba-con una distribuidora propia de cine" (166). However, at a closer look, the differences between the two models are worth exploring to further shed light on the Venezuelan particularism of the Chávez-era National Film Platform and question the Cuba/Venezuela comparison.

Unlike Chávez's turn to filmmaking later on in his presidency, the Cuban revolutionary government established the National Film Institute, ICAIC, within three months of reaching Havana in 1959 making the state/film relationship a priority from the start, linking politics and filmmaking. Cuban film expert Michael Chanan explains "Havana would become the second home of radical filmmakers throughout the continent, just as it became the champion of anti-imperialism and a leader of third-world nations" (6). The creation of the ICAIC included ousting past private film companies, nationalizing all cinemas in the country, and placing nearly all resources under the control of the ICAIC as the filmmaking institution that included funding, production, distribution and exhibition with limited exceptions. 
Graphic to represent Cuba's vertically organized film institute ICAIC from 1959 forward

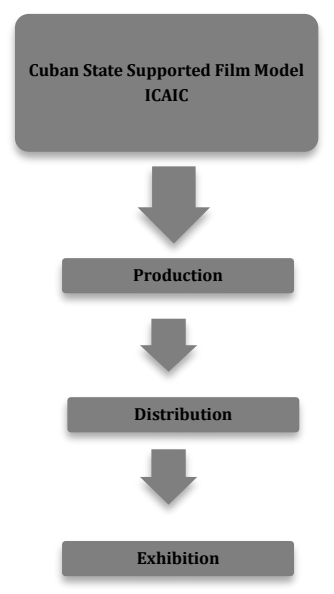

With the creation of the ICAIC came a form of new beginning for Cuban film, nearly erasing past pre-revolutionary film initiatives and film archives (García García). This new beginning led to a near complete monopoly on filmmaking in a vertically organized structure.

Unlike the forced clean slate that the Cuban Revolution created in 1959 dismantling previous institutions and the creation of a single institution responsible for almost all aspects of filmmaking [ICAIC], film under Chávez combined the past with the present. In Venezuela politically aligned new institutions such as La Villa, coexisted with decades 
old institutions from past governments marking a key difference between the Cuban and Venezuelan film initiatives.

Given these contrasts between the Cuban and the Venezuelan models, and the remarkable boom in Venezuelan annual film production, the National Film Platform and the films it releases remain an under-researched area in film studies, production studies, and Latin American studies. There is a select group of scholars from Venezuela and beyond working on this body of films and state initiatives, including Burucúa, DunoGottberg, Isea, Solli, Suárez, Vázquez, Villazna, and Zweig yet the Venezuelan film/state relationship remains in need of further research and visibility.

\section{Chávez and His Turn to Film:}

Unlike the Cuban Revolution's immediate dedication to film in 1959, the significant relationship between Chávez and Venezuelan state film did not form at the beginning of his administration in 1999. Instead his turn to film became explicit in the second half of his presidency in 2005, which coincided with a series of key events. One of the crucial events that revealed the contemporary power of film was the blockbuster success of the privately funded movie Secuestro Express, which premiered in Caracas on August 12, 2005. The privately-made Venezuelan film was an immediate success with audiences: "It was like a plasma bomb that not only shattered box office records but also the national conscience... This Miramax distributed film showed the problems that have transformed Venezuela into a caged animal" (Flores). The government was outraged over the success of this critical film portraying much of the daily street violence in contemporary Caracas often unaddressed by the Chávez government. However it was not 
the daily street violence alone that struck a nerve with the government. Instead the problem was with the use of the controversial and highly politicized archival footage of the April 11, 2002 shots from the Llaguno Bridge onto protesters below during the 2002 coup that served as the opening images of Secuestro. In response to the film Venezuela's vice president José Vicente Rangel denounced Secuestro as a "falsification of the truth with no artistic value" (Forero 2). While the film included the divisive archival footage from the 2002 coup, Venezuelans on both sides of the coup flocked to see the 2005 film. As Burucúa writes:

what the film [Secuestro Express] made manifest was the need for someone to say and show something beyond the dichotomy upon which rests the discursive struggle in which the government, on one side, and the opposition and the media, on the other, have been engaged for over a decade, reaching a confrontational climax around the time of the film's release, for it was in November 2005 that the controversial law of national cinematography was implemented. (Burucúa) After Secuestro's release the government showed a vested interest in promoting Venezuelan domestic film production, distribution, and access supported by the state, possibly in opposition to representations of Venezuela such as Secuestro. After publicly criticizing the film premiered in August 2005, followed by various lawsuits against the film's director Jonathan Jakubowicz, it was in this heady climate that the government announced the new Venezuelan Cinematography Law on October 26, 2005 and began to lay the foundations for institutions such as La Villa while reviving others. 
The 2005 film law "la Nueva Ley de Cinematografía Venezolana" added provisions to its 1993 Venezuelan film law predecessor ${ }^{2}$. Similar to the 1993 law, the 2005 law focused on supporting and encouraging national film production. However unlike the previous 1993 cinematography law, the 2005 law also actively supported ensuring domestic spaces for distribution and exhibition, two crucial and often unimplemented aspects of film legislation. To achieve that, the law established minimum distribution and exhibition requirements of national film, revisiting the topic of screen quotas (Villazna 167). These exhibition requirements were implemented in both state and privately run cinemas. With its 2005 film law quickly put into effect, Venezuela's film production remarkably increased, reaching a record of over 50 Venezuelan feature films released in 2014. To put this in perspective, prior to the November 2005 law, in 2004 there were a total of 4 domestic films released, followed by 4 in 2005 . After the 2005 law the domestic releases jumped to 11 in 2006, 13 in 2007, 32 in 2008, and 9 in 2009 (CNAC, "Periodo"). During the past Venezuelan film boom of the 1980s, an exceptional production year was 16 Venezuelan-made feature films, with a more typical average closer to 9 films per year (CNAC, "Periodo"). The 2005 film law, along with a series of factors, has contributed to the increase in Venezuelan film production.

Whilst in that sense the film law has been successful, it was not new legislation and film quotas alone that enabled this increase in Venezuelan national filmmaking under Chávez. It was also a maze of state infrastructure, which included previously established, repurposed, and brand new institutions that make up the labyrinth of the National Film Platform under the Ministry of Culture reflecting a continuation and change with the past.

\footnotetext{
${ }^{2}$ See "Proponen reformar ley de cinematografía...", for an analysis of the 1993 film law.
} 
Through these new and revived institutions two of the most innovative ingredients in Venezuela's boom in cinema were popular participation in filmmaking, and inexpensive access to these films throughout Venezuela that a close analysis of these institutions will reveal.

\section{The National Film Platform:}

Since Chávez’s remarks the Venezuelan film initiative of the Bolivarian government has resulted in over 400 documentary and community-made films, in addition to the mentioned over 50 Venezuelan feature-length films in 2014 ("Más de"). Chávez's turn to movie making matched his interest in national television screens as with the program Aló Presidente, and furthered his knowledge of the power of media. His words, personal image, and the historical context contributed to the phenomenon that became President Chávez to support a national paradigm shift towards a 21st century Bolivarian Revolution during his presidency between 1999-2013. Zweig explains that, "the Venezuelan state is using the 'magic; of communication image and media, of which Villa del Cine is a central part, to produce its "Bolivarian Citizen"” (141). Due to the ubiquitous images of state films that freely circulated and continue to flow through the newly established film networks, cinema has played an active role in constructing and sharing the messages of the Venezuelan narratives of the Chávez presidency.

From 2005 until 2013, the Chávez administration wove a larger complex web of organizations to create the National Film Platform. The Platform was under the jurisdiction of the Ministerio del Poder Popular para la Cultura established on February 10, 2005. The extended network of organizations and massive film projects, collectively 
known as the Venezuelan National Film Platform (and since renamed the Film and Audiovisual Media Platform in 2012) requires filmmakers and future audiences to negotiate how these agencies function, and interact (or not) with each other in order to take advantage of the social programs, training opportunities, educational workshops, and funding benefits to promote Venezuelan film.

The Platform is composed of five separate organizations under a common objective to extend opportunities to produce, distribute, exhibit and restore Venezuelan film. The previously mentioned Villa del Cine (2006) is the national production company; Amazonia films (2006) is the national distributor; the National Autonomous Cinematography Center (CNAC) (1993) is the financial arm of the industry; the Cinemateca Nacional (1966) is the national archive and exhibitor; and the National Disc Center (CENDIS) (2007) is the reproducer of discs and copies (for both films and music). During the Chávez administration each of these institutions had its own selection committee, funding, and was not required to work with the others. These institutions ran the risks of having conflicting programming, overlapping agendas, and challenges in communication. Despite the labyrinthine structure, lack of hierarchy and duplicated efforts it also created a possible space for different institutional agendas, politics, voices, and films.

The newest and most contentious of these organizations, La Villa del Cine, is a production studio located 30 miles from Caracas, and is charged with the state's production of films to facilitate public cinema. As the production arm of the Film Platform, it does not offer direct funding. Instead it gives production resources, including equipment and teams of workers, to projects the committee deems consistent with the 
annual theme. The themes can include a range of topics, from national heroes to social injustices.

One way that the Villa can offer direct funding is through contracting established Venezuelan directors to create feature-length films and to attract domestic and international audiences. Past Villa films that enjoyed international success include Luis Alberto Lamata's Miranda Regresa (2007), Román Chalbaud's Zamora (2009), and Fina Torres' Habana Eva (2010) among others. Many Villa movies, such as Miranda Regresa (2007), Zamora (2009), and Libertador (2013), highlight the connection between the past Venezuelan struggle for independence and the current ideals of the Bolivarian Revolution strengthening the government's narrative and legitimacy with "the objective to 'discover' a veiled history" (Valladares-Ruiz 64). Yet as Villazana explains "Si bien es importante recuperar la memoria y re-exponer el pasado para crear firmes cimientos de identidad e independencia, también es necesario evitar el absolutismo. Los guiones venezolanos no necesitan estar exclusivamente avocados a revivir a Miranda, a Zamora" (167). This constant return to the past to celebrate historical national heroes versus villains coupled with access to exceedingly large budgets to do so works against the Villa further blurring the division between filmmaking and direct propaganda.

Due to its explicit relationship with the Chávez administration many filmmakers have become hesitant to work with the Villa. As Hellinger writes "veteran filmmaker Alfredo Anzola complains that too much money is going into big-budget productions promoting the president's agenda" (2). To its critics, Villa films are too close to a propaganda arm of the government while also losing the original mission of promoting a different form of cinema. Muñoz further explains 
The creation of the Villa del Cine, ... a studio similar to the old Italian Cinecittà, has given historically weak movie production a certain professional and industrial air. However, the system of checks and balances that existed in the past has been tossed aside. The best proof of this is Chavez's direct granting of US\$18 million — an amount equivalent to the budget of nine Venezuelan films - to Hollywood actor Danny Glover to make a film in Venezuela about Haiti’s liberation.

This lack of checks and balances and possible cronyism shows a divide between the original discourse that recycles the messages from New Latin American Cinema and its big-budgeted implementation.

The Villa does not only contract established Venezuelan and international directors and actors for expensive historical bio-pics. Instead it also provides support for new filmmakers to apply directly to the Villa with a proposal, script, and a detailed list of production needs to execute their project. If the project fits the year's theme, and the Villa's committee deems it worthy, then the Villa supplies the director(s) with the resources needed according to the project's detailed list. The Villa holds open public calls for specific types of applicants: first-time screenwriters, first-time directors, and novice filmmakers aligned with the chosen theme. For example, one of the public calls for scripts and applications was for films with social critique. The winning application in 2008 was the film 1,2,3 Mujeres (2008), which is a series of three vignettes focusing on women protagonists struggling to make ends meet. The winning novice scriptwriters, Andrea Herrera, Anabel Rodríguez, and Andrea Ríos, turned the three vignettes into a full-length film. Resulting from a similar public call is the successful film Bloques 
(Alfredo Hueck and Carlos Caridad Montero 2008) also a collection of stories on the difficulties of daily life, loneliness, and urban struggle. The movie Libertador Morales, el justiciero (2009), with Villa support from the open call for scripts, is a comedy following a modern-day Bolívar-like character from a popular neighborhood fighting street crime and returning order to the streets of Caracas. The hero/villain binary also dominates many of the Villa's more contemporary works such as La Clase (2007), Libertador Morales, el justiciero (2009), and Hermano (2010) as well as in Villa supported documentaries such as Víctimas de la democracia (2009) and Venezuela Petroleum Company (2007). Between large budget films and open calls for first-time directors in 2012 alone, La Villa contributed to 34 full-length fictional and documentary films ("La plataforma...").

\section{The CNAC:}

While the Villa offers production support in terms of resources, the National Autonomous Cinematography Center (CNAC) is the financial arm of the Venezuelan Film Industry. It is located in Los Ruices, Caracas, and was first established in 1993 as a result of the 1993 Cinematography Law. As the financial arm of the Film Platform, the CNAC earns funds from taxes and enforces film legislation. While the CNAC is not a product of the Chávez administration, its current funding sources changed with the passing of the 2005 National Cinematographic Law. Article 31 of the 2005 National Cinematographic Law requires that, of the films screened by private and commercial cinemas, a minimum of twenty percent must be Venezuelan films. The CNAC receives its funding not directly through the government but through the FONPROCINE film tax established in 2007, created through article 36 of the 2005 National Cinematography Law, that charges each commercial film 5\% of each sold ticket in order to exhibit in 
Venezuela ("Asamblea Nacional"). The CNAC finances movies through this tax revenue and a combination of public (tax) and private funding.

The financial aspect is not the only major difference between the Villa and the CNAC. The CNAC selection committee is separate from the Villa and therefore often supports a form of filmmaking that may not follow the Villa's set theme for the year. The CNAC supported films often times do not directly support or may offer criticism of the national project as is the case with films such as Postales de Leningrado (2007), Azul y no tan Rosa (2012), and Pelo Malo (2013). These films have premiered at competitive international film festivals such as Spain's San Sebastián Film Festival in 2013, and New York's Tribeca Film Festival in 2014, and have won numerous awards from a Goya to a Concha de Oro. The CNAC supported the above films along with a combination of state and outside funding.

In order to administer the diverse types of funding, the CNAC holds its own open calls for proposals, and these competitions are focused on attracting projects different from those of the Villa. For example, the CNAC holds contests for scripts to promote scriptwriting, while the Villa often looks for new directors. These diverse open calls for competitions for funding and resources through each of the five organizations further differentiate a more horizontal Venezuelan model from the centralized and vertically organized Cuban model. The CNAC has changed its objective since the overall transformation of the Cultural Ministry and Film Platform in 2005. Prior to 2005, the majority of the CNAC film funding was awarded to a small group of established filmmakers. To promote participation in the filmmaking process, the CNAC has since 
focused partly on new filmmakers working on first time full-length films, while also backing established filmmakers.

While the CNAC and the Villa both support new and established artists, the types of projects greatly differ, as well as the role of the organization in the content of the film. For example, when asked about the state's funding role in making the film Pelo Malo (Rondón 2013), director Rondón explained, "Like all films from the CNAC it is an autonomous institution that holds competitions, if chosen you get 50-60\% of the film's budget - also the CNAC is a great help for distribution" (Rondón). The director highlights that it is a source loosely connected to the state through taxes to support nonpartisan filmmaking.

Some of the most internationally acclaimed contemporary Venezuelan films have directly benefitted from the CNAC instead of the Villa, as is the case for Pelo Malo. While continuing with a local focus on telling Venezuelan stories, this Concha de Oro award-winning film challenges a clear relationship between heroes and villains often found in the grand historical narratives of Villa films such as Miranda Regresa and

\section{Libertador.}

Through an intimate look at the film's main character Junior, a poor boy in the slums of Caracas, the audience witnesses the character's experience with racism, poverty, homophobia, and classism set in contemporary Caracas. As the camera briefly shows the pro-Chávez speeches, television shows, and billboards decorating the main streets of Caracas, the viewers soon realize that official institutionalized politics and the messages of the Opposition are both far from Junior's reality. Beyond current politics, Pelo Malo's critical look at pervasive intolerance does not present a solution to Venezuelan 
challenges. Instead it is an intimate story that leaves more questions than answers and contrasts with the large budget historical narratives of the Villa, yet still contributes to the boom in contemporary national production.

Other award-winning films have benefitted from a combination of sources from both the completely state funded Villa, and the private/publicly funded CNAC. For example, in 2014, the film Azul y no tan Rosa won the Goya award for Best Spanish Language Foreign Film. In an analysis of its funding, it benefitted from a mosaic of institutions that contributed to the film with $57.6 \%$ of financing from the CNAC and 19.2\% by the Villa ("Para la película"). While receiving a collaboration of funding, it also cannot be considered a film solely supported by the National Film Platform. Given the CNAC's flexibility in allowing for diverse funding combinations, this film also secured funding from the co-production fund Ibermedia ${ }^{3}$, of which Venezuela is a contributing member country. Also differing from the overtly pro-government films often glorifying the Bolivarian Revolution, the film both exposes a critical look at homophobia and also cultivates tolerance in its story line, concluding with a representation of a contemporary Venezuelan family breaking with a traditional past.

The differences between the CNAC and the Villa are not only apparent in terms of funding relationships with the state, but also when approaching the post-production life of a film. Upon receiving funding from the CNAC, the director is not obliged to use the state distributor Amazonia Films, nor does the director need to give all movie rights to the CNAC. This institution also offers funding for shorts and community films. A separate selection committee decides on the winners of each of these competitions and

\footnotetext{
${ }^{3}$ See Alvaray for an insightful analysis on Ibermedia and contemporary funding in
} Latin American film. 
the winners are able to combine their monetary awards with other funds from the remaining organizations in the Platform.

In terms of the CNAC working with the various institutions of the Film Platform, the CNAC cooperates with the other organizations in planning the annual Margarita Film Festival, held on the Venezuelan island of Margarita, which is another recent addition to the film landscape in Venezuela. While there may be communication among the organizations for events such as the Margarita Festival, they are independent of each other, with separate selection committees, budgets, presidents, and agendas. For example instead of all of the organizations directly supporting one community's cinema project the CNAC had its own separate pilot program called Cine de la Calle to support and share film with diverse audiences. The pilot program was a test in five different popular plazas in Caracas where the CNAC showed films by installing inflatable movie screens in public plazas. The program's focus was to share Venezuela's contemporary and classic films with the audience in public spaces. However, one of the constant problems of this pilot program is a lack of communication between institutions, in this case between the CNAC and the Cinemateca. The lack of communication has meant a significant overlap in programming. Also the CNAC's Cine de la Calle is an example of the continuation of the historically Caracas-centered film programming, which is a challenge that some of the institutions have attempted to address, but continues to hover over these initiatives.

\section{VI: The Cinemateca Nacional:}

One institution that has worked to address the decades long tradition of film initiatives based solely in Caracas is the Cinemateca Nacional. In 1966, in conjunction with the French Cinemateque, Venezuelan filmmaker Margot Benacerraf established the 
Cinemateca to share the diversity of cinema from Brazilian Cinema Novo to European silent film throughout Venezuela. In 1990 the Cinemateca was reorganized into a foundation, opening its focus to include film publications such as the film journal Objeto Visual, television programs, and a film archive. Having changed greatly since its establishment in 1966, the Cinemateca Nacional is an exceptional addition to this web of organizations that made up the National Platform under Chávez. Until 2005 the Cinemateca was composed of two cinemas in Caracas and has significantly increased its number of theaters to include a network of hundreds of community and regional cinemas throughout Venezuela. The Cinemateca uses these newly inaugurated cinemas to make film accessible for free in the community theaters and at a nominal price in the regional network. The cinema network addresses two of the most difficult challenges with $21^{\text {st }}$ century Latin American film and of the 2005 National Cinematography Law: distribution and exhibition. This network of theaters is arguably one of the most participatory and significant aspects of the National Platform, yet the Cinemateca is also the least researched institution of the Platform.

These community cinemas may prove over time to be spaces for discussion, dissidence, dialogue, or organization. It is precisely spaces like the community cinema network that show the key differences between the current National Film Platform and the past state investments in film in both Venezuela and the region. It is not, however the first time in Venezuela that there is a film-forum movement in communities. In the 1980s there were student cinema clubs that traveled to poorer communities to show and discuss films. The difference is that the recently established networks make film available in areas in an organized way instead of ad hoc film showings. 
A centralized programming team in the Cinemateca in Caracas programs films that are more difficult to find for the general public, including art house films, documentaries, children's films, international cinema (including US independent films), and of course contemporary Venezuelan cinema, such as the films supported by La Villa. In order for the Cinemateca to open a community cinema and send the official monthly programming to the community cinema, they require that a community member in charge of the cinema agree to the monthly assigned film programming, secure a space large enough to fit 50 people, and create a safe place to store the film-viewing equipment. The community theater can serve another purpose during the day, and does not have to be public; it only needs to be open to the public while serving as a community cinema. The Cinemateca supplies the community cinema with projection equipment, fifty plastic seats, and film programming; they require four movies to be shown a week, and one of them has to be a children's movie. Also one of the four films needs to be open for a cinemaforum for film discussion. If the communities do not comply with the approved use of the cinema or are not using the theater, then the Cinemateca main office looks for another community leader to direct the space, or the community runs the risk of losing its equipment.

The community theaters are not only spaces to show feature-length films from Venezuela and abroad, but also for community-made cinema and the national community-made CNAC filmmaking competition. As of 2013, the sixth national competition for community film and video finished with 118 competing works exhibited in 115 community theaters and nine regional theaters (Liendo Jiménez). Through these 
recently established cinemas, the Cinemateca works to foster new film audiences and filmmakers at a local level.

In 2005 the Cinemateca began converting pre-existing buildings to create another network of cinemas: regional cinemas directly linked to the two principal pre-existing centers in Caracas. In the regional cinemas a ticket costs the equivalent of around US $\$ 1.50$ while the community theaters are free. Through these cinema networks, the Cinemateca works towards becoming an institution with a national reach rather than the historically Caracas-centered focus-with varying degrees of success.

Beyond exhibition, the Cinemateca also has the daunting task of restoring Venezuelan films and recuperating an abandoned film archive, using the recently acquired film restoration technology now available at the Cinemateca. During the Chávez administration the team worked on the restoration of thirty-five movies per year. Unfortunately the national archive had been overlooked for decades due to limited funding and past governments' varying commitment to the collection. While currently under renovation, it is nearly impossible to find a working copy of missing films regardless of their national importance to the Venezuelan film canon. This difficulty to access a complete national film archive has contributed to a lack of general knowledge of Venezuela's film history. The Cinemateca faces the challenge to recuperate years of sporadic film investments and to recreate the incomplete archive.

\section{Conclusions:}

Since Chávez’s death in March 2013 Venezuelan state film support has already changed. In February 2014, under current president Nicolás Maduro, the controversial Villa was removed from the jurisdiction of the Ministry of Culture and reassigned to the 
Ministry of Communication (MinCi). This change has underlined a much larger theoretical question on the distinction between film as a cultural art form or a means of propaganda. Also the change further complicates the unique horizontal organization of the National Film Platform of the Venezuelan film landscape. The Maduro administration's decision to reassign the Villa del Cine has caused a backlash from Venezuelan filmmakers, intellectuals, and journalists expressing their disagreement with the change, the break of the Platform, and an overarching fear of completely dismantling this delicate and possibly chaotic balance of a heterogeneous web of filmmaking possibilities in Venezuela. The move has resulted in popular national newspapers with headlines such as “¿Villa de la propaganda?” (El Universal); and "El control aumentará en el cine nacional" (La Nación). It has brought into question the future of Venezuela's unique model of past autonomous institutions coexisting with politically aligned ones that made up the Chávez-era particularism of the National Film Platform.

In the midst of this tension about the future of the state's role in the film industry, on June 4, 2014 the president of La Villa del Cine, José Antonio Gómez, announced an open call for scripts for a new feature film about Hugo Chávez ("Abren convocatoria") For now we can only wait to see what will become of this state-supported open call for scripts on Chávez. As 2013 and 2014 marked an all-time high for Venezuelan film in terms of quality, quantity, and visibility, the recent change in the jurisdiction of La Villa and the call for a feature length film on Chávez paint a different picture for the next chapters in Venezuelan national film and possibilities for public support without explicit censorship or control. These changes threaten the potential spaces for diverse and at 
times conflicting forms of filmmaking that were, to some level, protected in the National Film Platform under Chávez.

Despite an impressive increase in Venezuelan filmmaking, an aggressive cinema law, new distribution prospects, and additional exhibition spaces, the National Platform continues to face challenges. It still has not found a solution for decades of Caracascentric institutions. All five of the film institutions are physically based in or close to Caracas, and, with the exception of the annual Margarita Film Festival, do not hold significant film events outside of Caracas. Although the Cinemateca created regional and community cinemas to address this problem, the planning committee remains in Caracas. Also, with a lack of communication between institutions, filmmakers seeking state support often have numerous in person meetings in Caracas to discuss available opportunities, which reinforces Caracas-centric initiatives.

Another persistent challenge is the incomplete film archive that has suffered various abandoned preservation and restoration programs over the decades. While the Venezuelan state's interest in film is not entirely new, the evidence of previous Venezuelan blockbusters is difficult or impossible to access. The deficient archive further adds to Venezuela's lack of visibility in the film world, and film studies. The Platform has begun to address the importance of preservation and archiving, but it is an uphill battle with many parts of the Venezuelan film canon already lost.

Only time will tell what will happen with future changes to this particular approach to film support and if the unprecedented boom in filmmaking will continue in contemporary Venezuela. 


\section{Bibliography}

1,2,3 Mujeres. Dir. Andrea Herrera, Anabel Rodríguez and Andrea Ríos. Fundación Villa del Cine, 2008. Film.

“Abren convocatoria de guiones para película sobre Hugo Chávez.” El Universal [Caracas, Venezuela] 4 June 2014. Web. 1 Oct. 2014. <http://www.eluniversal.com/arte-y-entretenimiento/140604/abren-convocatoriade-guiones-para-pelicula-sobre-hugo-chavez>

“Aló, Presidente 257”. Aló, Presidente. Los Venados, Parque Nacional El Ávila, Distrito Capital. 4 June 2006. Television.

Alvaray, Luisela. "National, Regional, and Global: New Waves of Latin American Cinema.” Cinema Journal 47.3 (2008): 48-65. Print.

Asamblea Nacional de la República Bolivariana de Venezuela. Ley de la Cinematografía Nacional. Gaceta Oficial de la República Bolivariana de Venezuela 5.789 (26 Oct. 2006): 9-14.

Azul y no tan rosa. Director Miguel Ferrari. CNAC. 2012. Film.

Belinchón, Gregorio. “Tras las polémicas... la película.” El País. 13 Mar. 2014. Web. 23 Nov. 2014.

Bloques. Dir. Alfredo Hueck and Carlos Caridad Montero. Fundación Villa del Cine, 2008. Film.

Burucúa, Constanza. "Representing Conflict and Otherness in Contemporary Venezuelan Cinema.” University of West Indies, Augustin Campus, Port of Spain, Trinidad. 25 Sept. 2012. Keynote Address.

Chanan, Michael. Cuban Cinema. Minneapolis: University of Minnesota Press, 2004. 
Web.

"Cinemateca Nacional cerrará el año con casi 200 salas de cine comunitarias." 17 July 2007. Misión Cultura: Gobierno Bolivariano de Venezuela: Ministerio del poder popular para la Cultura. Web. 3 Nov. 2007.

<http://www.misioncultura.gob.ve/notmision.php?id=1359>.

CNAC: Centro Nacional Autónoma de Cinematografía. Gobierno Bolivariano de Venezuela: Ministerio del Poder Popular para la Cultura. Web. Sept. 2007. $<$ http://www.cnac.gob.ve/>.

---. “Periodo Referencial 1976 al 2011: Obras Cinematográficas Venezolanas Estrenadas." 2011.<http://www.cnac.gob.ve/?page_id=428. Web. 4 April 2012. Cooper, Amy. "What does Health Activism Mean in Venezuela's Barrio Adentro Program? Understanding Community Health Work in Political and Cultural Context." Annals of Anthropological Practice 39.1 (2015): 58-72. Print.

Dineen, Mark. Culture and Customs of Venezuela. Westport, Conn: Greenwood Press, 2001. Print.

Duno-Gottberg, Luís and Forrest Hylton."Huellas de lo Real: Testimonio y Cine de la Delincuencia en Venezuela y Colombia." Miradas al Margen: Cine y subalternidad en América Latina y el Caribe. Ed. Luís Duno-Gottberg. Caracas: Fundación Cinemateca Nacional, 2008. 247-285. Print.

Fernandes, Sujatha . Who Can Stop the Drums? Urban Social Movements in Chávez's Venezuela. Durham, NC: Duke University Press, 2010. Print.

Flores, Carlos. “Jonathan Jakubowicz: 'Maduro mata gente y sale bailando con su esposa en cadena nacional."” Huffington Post. 25 Feb. 2014. Web. 4 July 2014. 
Forero, Juan. "Venezuelan Filmmaker Finds His Kidnapping Tale Resonates With the Masses." New York Times. 6 Oct. 2005, late ed.: p.E.3. Print.

---. "Venezuela's Chavez Promotes Nation's Films.” National Public Radio. 9

Oct. 9, 2007. Web. 12 October 2014.

Franceschi, Karla C. "El control aumentará en el cine nacional.” El Nacional. Caracas, Venezuela. 14 July 2014. Web. 25 Sept. 2014. <http://www.elnacional.com/escenas/control-aumentara-cine-nacional_0_443955791.html>.

Gallegos, Rómulo. Doña Bárbara. Cátedra,1997. Print.

García Espinosa, Julio. "Por un cine imperfecto”. 1969. Web.

García García, Alicia. “¿Democracia de la memoria, es posible? Cinemateca de Cuba: Antecedentes, trayectoria y presente." Latin American Studies Association. Chicago, Illinois. 24 May 2014. Conference Presentation.

González, Rodrigo M. "Vida de Simón Bolivar inspira la cinta más cara del cine latinoamericano." La Tercera. 9 Nov. 2013. Web. 8 Oct. 2015.

Hellinger, Daniel. "Chávez and the Intellectuals." NACLA Report on the Americas 45.4 (2012): 51-2. Print.

Hermano. Dir. Marcel Rasquin. A\&B producciones y CNAC, 2010. Film.

Ingham, James. "Venezuelan Cinema, Chavez Style." BBC Online. 1 Nov. 2007. <http://news.bbc.co.uk/2/hi/americas/7070799.stm〉.

Isea, Antonio M. "Masculinidad, crimen y espectacularidad en el cine venezolano del siglo XXI.” Latin American Studies Association. Chicago, Illinois. 24 May 2014. Conference Presentation. 
Kozloff, Nikolas. Revolution! : South America and the Rise of the New Left. New York:

Palgrave Macmillan. Print.

La clase. Dir. José Antonio Varela. Villa del Cine, 2007. Film.

La Fundación Cinemateca Nacional. Gobierno Bolivariano de Venezuela: Ministerio del Poder Popular para la Cultura. Sept. 2007 <http://www.cinemateca.gob.ve/>.

“La Plataforma del Cine y Medios Audiovisuales se consolida en el 2012.” Ministerio del Poder Popular para la Cultura. Web 25 Sept. 2014. $<$ http://www.mincultura.gob.ve/index.php/component/content/article/11prensaweb/actualidad/2233-la-plataforma-del-cine-y-medios-audiovisuales-seconsolida-en-el-2012>.

"La Villa del Cine." 2007. Misión Cultura: Gobierno Bolivariano de Venezuela: Ministerio del poder popular para la Cultura. 3 Nov. 2007. Web $<$ http://www.villadelcine.gob.ve/villa.php?canal=inicio>.

Libertador. Dir. Alberto Arvelo. Fundación Villa del Cine, 2013. Film.

Libertador Morales, el justiciero. Dir. Efterpi Charalambidis. Fundación Villa del Cine, 2009. Film.

Liendo Jiménez, Daniel. “Xavier Sarabia: Creación audiovisual se está elevando a la estatura del Pueblo.” Alba Ciudad. 2 Sept. 2013. Web. 23 Oct. 2014. $<$ http://albaciudad.org/wp/index.php/2013/09/xavier-sarabia-creacionaudiovisual-se-esta-elevando-a-la-estatura-del-pueblo/>

“Lights! Camera! Revolucion!” Newsweek. 2 Nov. 2009. Web. 23 Oct. 2014.

López, Ana M. "Early Cinema and Modernity in Latin America." Cinema Journal 40.1 (Autumn, 2000): 48-78. Print. 
"Más de 50 películas venezolanas están listas para ser estrenadas." Diario la Nación [Caracas, Venezuela]. 1 Jan 2014: Web. 25 Sept. 2014. $<$ http://www.lanacion.com.ve/farandula-y-espectaculos/mas-de-50-peliculasvenezolanas-estan-listas-para-ser-estrenadas/>.

Miller, Nicola. "A Revolutionary Modernity: The Cultural Policy of the Cuban Revolution." Journal of Latin American Studies 40.4 (2008): 675-96. Web.

Miranda, Julio E. Cine y Poder en Venezuela. Universidad de los Andes Consejo de Publicaciones Libreria Universitaria: Mérida, Venezuela, 1982. Print.

---. Palabras sobre imágenes: 30 años de cine venezolano. Monte Ávila Editores: Caracas, 1993. Print.

Miranda Regresa. Dir. Luís Alberto Lamata. Fundación Villa del Cine, 2007. Film. "Para la película "Azul y no tan rosa" el CNAC aporto 57.6\% del financiamiento mientras la Villa del Cine dio 19.2\%." MPPC/La Radio del SUR. Aporrea. 10 Feb. 2014. Web. 24 Oct. 2014.

Muñoz, Boris. "The Revolution of Conscience:Building a New Cultural Hegemony in Venezuela." ReVista: Harvard Review of Latin America. Fall (2008). Web.

Pelo Malo. Dir. Mariana Rondón. Sudaca Films, 2013. Film.

"Proponen reformar ley de cinematografía para potenciar crecimiento del cine nacional." Agencia Venezolana de Noticias. 2 June 2014. Web. 29 March 2016.

República Bolivariana de Venezuela. Fundación Misión Cultura. ¿Qué es la Misión Cultura? Caracas: Ministerio de la Cultura, n.d. Print.

Rocha, Glauber. "Aesthetics of Hunger." Twenty Five years of the New Latin American 
Cinema. Ed. Michael Chanan. London: British Film Institute Books, 1983. 13-14. Print.

Romero, Simon. “Chávez Takes 'Crazy Battalion' of Supporters on the Road.” The New York Times 4 Aug. 2007: Web.

Rondón, Mariana. "Post film Question and Answer Session for Pelo Malo." Tribeca Film Festival. AMC Loews Village 7, New York, New York. 22 April 2014. Address.

Secuestro Express. Dir. Jonathan Jakubowicz. Miramax, Caracas, 2004. Film.

Solli, Audon. "The Power of Film in Venezuela and Mexico: 1980-2010: Contesting and Supporting State Power.” Diss. Univ Of Oslo, 2014. Print.

Suárez, Belkis. "Cine Venezolano: proyecto cultural y práctica social en la representación de la nación.” Latin American Studies Association. Chicago, Illinois. 24 May 2014. Conference Presentation.

Valladares-Ruiz, Patricia. "Memoria Histórica y Lucha De Clases En El Nuevo Cine Venezolano. (Spanish)." Revista Hispánica Moderna (0034-9593) 66.1 (2013): 57-72. Print.

Vázquez, Mercedes. "Secuestro Express and La Clase: Politics of Realism in Contemporary Venezuelan Filmmaking." Jump Cut: A Review of Contemporary Media.52 (2010): 37-. Print.

Venezuela Petroleum Company. Dir. Marc Villá. Fundación Villa del Cine, 2007. Film. "Venezuelan President Hugo Chavez's Movie Studio.” Newsweek. 23 Oct. 2009. Web. Víctimas de la democracia. Dir. Stella Jacob. Villa del Cine, 2009. Film. “¿Villa de la propaganda?” El Universal. Caracas, Venezuela. 23 March 2014. Web. 25 Sept. 2014. <http://www.eluniversal.com/que- 
hay/140323/villa-de-la-propaganda-imp>.

Villazna, Libia. "De una política cultural a una cultura politizada: La República Bolivariana de Venezuela y su revolución cultural en el sector audiovisual.” E Pluribus Unum? National and Transnational Identities in the Americas (InterAmerican Perspectives/ Perspectivas Interamericanas 1). Eds. Josef Raab, and Sebastian Thies. Münster: LIT and Tempe, AZ: Bilingual Press, Inter-American Perspectives/Perspectivas Interamericanas 2008. 161-173. Print.

Zweig, Noah. "Villa del Cine (Cinema City): Constructing Bolivarian Citizens for the Twenty-First Century." Situations: Project of the Radical Imagination: Film Issue 4.1 (2011): 133-148. Print. 